Socialist Studies / Études socialistes 6(2) Fall 2010: 141-159

Copyright (C) 2010 The Author(s)

SPECIAL SECTION ON ROSA LUXEMBURG'S POLITICAL ECONOMY

\title{
The Current Relevance of Rosa Luxemburg's Thought
}

\author{
ESTRELLA TRINCADO \\ History of Economic Thought, Complutense University of Madrid. Madrid, Spain
}

\begin{abstract}
This article insists upon the current relevance of Rosa Luxemburg's thought. Luxemburg had a sensibility ahead of her time and, faithful to her dreams of revolutionary change, she searched for an open society. This leftist revolutionary did not believe in the contingency of individual freedom. Instead, she argued for movement and development over time as a perpetual objective of the globalized masses. Luxemburg sought a new type of socialism and even a new way of thinking. The basic idea of her political conception was the opening of the revolutionary horizon, a willingness to learn new things. Thus, she learned from classical economics and, at the same time, she was able to criticize them. Luxemburg anticipated many current economic theories that enable us to understand the contemporary crisis. Finally, some conclusions are drawn, taking stock of Luxemburg's theories and life.
\end{abstract}

\begin{abstract}
Resumé:
Cet article reconnait la pertinence et l'actualité de la pensée de Rosa Luxemburg. Luxemburg avait une sensibilité en avance sur son temps et, fidèle à ses rêves de transformation révolutionnaire, elle cherchait une société ouverte. Cette révolutionnaire de gauche n'a pas cru à la contingence de la liberté individuelle et a suggéré que le mouvement et le développement dans le temps étaient un objectif permanent des masses mondialisées. Luxemburg cherchait un nouveau socialisme et même une nouvelle manière de penser. L'idée de base de sa conception politique était l'ouverture de l'horizon révolutionnaire et une volonté d'apprendre de nouvelles choses. Ainsi, elle a appris de l'économie classique tout en montrant en même temps sa capacité à les critiquer. Luxemburg a anticipé plusieurs théories économiques d'aujourd'hui qui nous permettent de comprendre la crise actuelle. En fin, quelques conclusions sont tirées, faisant le point des théories et de la vie de Luxemburg.
\end{abstract}

\footnotetext{
Estrella Trincado is Lecturer in History of Economic Thought in the Complutense University of Madrid. She is a specialist in Rosa Luxemburg's thought and in the doctrine of classical economists. She has attended conferences (Madrid, Santiago, Dublin, Porto, Wuhan) and published academic articles establishing a link between Luxemburg's life and thought and tracing the classical economic origin of Luxemburg's thought (see Research in Political Economy 2004, Información Comercial Española 2009, Mujeres Economistas 2007, Ecobook). She can be reached at: estrinaz@ccee.ucm.es.

Estella Trincado est maître de conferences en histoire de la pensée economique à l'Université Complutense de Madrid. Elle est spécialiste de la pensée de Rosa Luxemburg et de la doctrine des économistes classiques. Elle a participé à de nombreux colloques (Madrid, Santiago, Dublin, Porto, Wuhan) et a publié des articles universitaires qui établissent un lien entre la vie et la pensée de Luxemburg et font émerger le lien entre celle-ci et l'économie classique (voir Research in Political Economy 2004, Información Comercial Española 2009, Mujeres Economistas 2007, Ecobook). Elle peut être contactée à estrinaz@ccee.ucm.es.
}

Socialist Studies: the Journal of the Society for Socialist Studies/Études socialistes: Revue de la Société d'études socialistes www.socialiststudies.com 
Socialist Studies / Études socialistes 6(2) Fall 2010: 141-160

Key Words:

alienation • classical economists • current crisis • openness • Rosa Luxemburg

Mots-clés:

aliénation • économistes classiques $\bullet$ crise actuelle $\bullet$ ouverture $\bullet$ Rosa Luxemburg

Recently, Rosa Luxemburg's thought has become especially relevant. For instance, the current economic crisis may be explained through the Luxemburgian thesis. According to Luxemburg, stock market or housing bubbles are a consequence of the fact that capitalism is not aimed at satisfying needs. Rather, its only aim is to create value: not to produce consumer products, but to make profit perpetually. The system creates great inequality, hunger and the relative dominance of speculative or financial economics. It is based on unemployment or unstable employment, militarism, the control of public opinion and the loss of citizens' decisionmaking capacities and ability to participate in shaping a desirable future.

Moreover, recent imperialist wars, such as those in Iraq and Afghanistan, have made the figure of Luxemburg current again. Her antimilitarism was a key element of her thought: she opposed the First World War and she was co-opted by movements in the 60's and 70's as an emblem, especially as a critic of the Vietnam War. Although this may seem strange with an internationalist author, antiglobalization movements have used Luxemburg's image ${ }^{1}$. Luxemburg argued that capital gain is only possible if we include consumers external to the capitalist system: the time will come when the extension of capitalism will make this system unfeasible and, if all the world is capitalist, the final crisis will occur and the system will be replaced with a truly international one, in the good sense of the word.

Finally, Rosa Luxemburg has been in the news again: according to German authorities, the remains found in the forensic Institute of Berlin have led to the exhumation of a beheaded corpse which could be the remains of the assassinated revolutionary. It seems that the body buried the year of her assassination was not hers: it lacked the hip defect that she

${ }^{1}$ See Drainville (2005), Slavin (2006) or Löwy (2009). Schütrumpf (2007) regards Luxemburg as highly modern and relevant today; she is increasingly popular with globalization critics, particularly in Latin America. In the 1980s critics of globalization on the left saw it as a new form of imperialism that relies on economic domination rather than direct military conquest. Thus, anti-imperialists began to focus on opposing globalization, and they contributed to giving birth to the present-day antiglobalization movement. In Germany, where there is a resurgence of interest in Marxism, Luxemburg also looks ripe for a renaissance. 
TRINCADO: The Current Relevance of Rosa Luxemburg's Thought

suffered, with one leg longer than the other. ${ }^{2}$ Subsequent tests have determined that the corpse found recently was that of a woman between forty and fifty years of age, who had suffered from osteoarthritis and whose legs were of different lengths. The previous corpse lacked the rifle butt blows that Luxemburg received on the head or the shot in the head that is supposed to have caused her death. Conversely, the body found in Berlin shows obvious signs of drowning, according to Der Spiegel, with missing extremities since weights were tied to Luxemburg's hands and feet before she was thrown into the canal: when the water froze, the limbs would have separated.

However, Rosa Luxemburg refused to go through life acting like a victim, and we are not going to victimize her. Perhaps avoiding that victimization was the key to avoiding discrimination as a woman certainly, being a woman did not hurt her as much, for instance, as her hip defect. That does not mean that her sex was not a constraint on her activity and to disseminating her ideas. It took another woman, Joan Robinson, who in 1951 published Rosa Luxemburg's most well-known book, The Accumulation of Capital, to admit in a fifteen-page introduction that she was the first to study an economic subject as important as the inducementto-invest. Luxemburg created a theory of capitalism's dynamic development, anticipating twentieth century growth models by emphasizing the growth of effective demand (Trincado 2001).

In this article, we seek to demonstrate Luxemburg's far-sighted sensibility and, defying any tendencies to victimize her, we emphasize her current relevance. As a dialectic materialist, practice and theory was for her one and the same; her own life and political struggles are perfectly coherent with her theory. She faced life and resisted, struggling against the 'givens' of nationalism, bureaucratized union and party politics, and the supposed inevitability of capitalism: this was her work of art. Luxemburg remained faithful to her dreams of a revolutionary change, searching for an open society and fighting against the endogamy she found in her way. In so doing, she created a new concept of alienation. Luxemburg emphasized movement and development in time as a perpetual objective of the globalized masses. At the same time, Luxemburg proposed an open

\footnotetext{
${ }^{2}$ When she was two years old, Luxemburg fell ill and doctors diagnosed tuberculosis, which proved to be a hip inflammation that was not correctly treated. As a result, the joint did not fit well and Rosa walked with a slight limp for the rest of her life. In the course of time, that limp was to make it easier for the police to identify her every time she took part in demonstrations and when she was forced to flee.
} 
Socialist Studies / Études socialistes 6(2) Fall 2010: 141-160

economic theory that anticipated many concepts mobilized to understand the current economic crisis. Finally, some conclusions shall be drawn, taking stock of Luxemburg's theories and life.

\section{Against Endogamy}

As a child in the little Polish town of Zamosc, Rosa Luxemburg showed herself to be an idealist; she dreamt of a revolutionary change: 'My ideal is a world where I could love everybody in peace. In pursuit of that goal, maybe once I will need to learn how to hate' (Seidemann 2002, 9). She wrote this inscription in 1887, when she was seventeen years old, on the back of a photo she gave to a classmate for high school graduation.

Her studies acquainted her with the writings of Adam Smith and other moral philosophers, and her bent led her to radical writers, such as Marx and Engels. While still a student, she became actively involved in politics. There, in her twenties, she met Leo Jogiches, a twenty three-yearold political organizer. He trained her in revolutionary practice. However, they had differences in their understanding of revolutionary organization and their relationship suffered under the strain of Luxemburg's professional success. Professional life finally won and Jogiches and Luxemburg separated when she finished The Accumulation of Capital (Frölich 1972).

Although Jogiches did not accompany Luxemburg, her idealism did and she always sought the advent of that Utopian world in which 'our worlds will not be reduced to searching for the property of our home as we will feel the whole world as our home' (Luxemburg 1914, 4-5). To the end, she followed her libertarian principles and, although she defended social revolution, she also displayed a spark of genius at the outbreak of the first Russian revolution when she became indignant at how it was unfolding. This is because Rosa Luxemburg defended a Mensch, a 'true human being' with an open mind, very different from that of her male comrades. From prison, she wrote: 'Being a true human being means happily throwing one's life "on fate's great scale" if necessary, but, at the same time, enjoying every bright day and every beautiful cloud. Oh, I can't write out a prescription for being a true human being' (Luxemburg to Emanuel and Mathilde Wurm, 12/28/16, in Luxemburg $(1993,173))$.

Luxemburg searched for openness in theory and practice, fighting against the endogamy she found in her life (Trincado 2004). For instance, although Marxist scholars typically understate Luxemburg's involvement in feminism, Luxemburg sought to collaborate with women's liberation movements and defended the role of women in revolution. Though it was 
TRINCADO: The Current Relevance of Rosa Luxemburg's Thought

not strange for socialist women to distrust women's suffrage (as was the case in Spain with Victoria Kent), Rosa Luxemburg called for women's suffrage, linking it at all times with the broader issue of general liberation. Her friendship with Clara Zetkin, founder of the women's liberation movement as a mass labour movement, was crucial. However, Zetkin decided to focus on organizing women, while Luxemburg extended her range of interests. In a situation of general oppression, her concerns could not be centered only on women. But Luxemburg helped the women's movement by collaborating with the journal Equality, which was edited by Zetkin. In 1907, she participated in the International Conference of Socialist Women and stressed the importance of women having their own voice heard (Dunayevskaya 1982). She knew well about being doomed to remain silent: although she was the editor of the social democrat journal, when she arrived in Germany in 1898 she found that the male members of the party were not willing to grant her the same powers they had allowed her male predecessor. Her complaints to Bebel did not improve the situation and shortly afterwards she resigned, although she did not make this issue a part of what was then called the 'women's question'. In party controversies, when disagreement with the core of the orthodox leadership of Bebel and Karl Kautsky emerged in 1910-11, the latter spoke with a special sarcasm that no male opponent would have had to endure. Finally, members of the socialist party tried to limit her work to the women's question. However, she emphatically refused to let herself be classified.

Luxemburg also faced and rejected the endogamy of nationalism. In her thesis The Industrial Development of Poland, for which she was awarded a PhD in Philosophy and Law from the University of Zurich in 1897, she criticized nationalistic reconcentration (Luxemburg 1977). In 1772, Poland fell under Russian domination. There were several Polish insurrections that were bloodily repressed. Only following the Treaty of Versailles after the First World War, was Poland made independent. In her thesis, Luxemburg demonstrated that Russian Poland had become so dependent on the Russian market that the political demands for independence were unrealistic. Her opposition to the independence of Poland was not very popular among the nationalistic Polish Socialists. The fact that she objected to the self-determination of Poland could only lead to her isolation from the socialist Party, as Lenin shows (1963a, 1963b, 1963c, 1963d, 1963e). Some Party comrades, she claimed, used to say that a woman's place was in the home. But, in fact, as Cliff (1960) remarks, in the final analysis, by not supporting Polish independence Luxemburg was following the spirit of 
Socialist Studies / Études socialistes 6(2) Fall 2010: 141-160

Marx and Engels. The latter defended Polish independence because they sought internationalism. Luxemburg criticized Polish independence, but for the same reason.

Like Marx and Engels, Luxemburg did not want to accept an absolute criterion for judging the struggles for national independence. In 1848, Marx and Engels thought that the enemies of the democratic revolutions were Czarist Russia and the Austria of the Hapsburg dynasty. The independence of Poland might create a barrier to both. But over time, Czarist Russia began to totter, and in Russia a socialist revolution was taking place. At that moment, there was no influential social force in Poland interested in national independence. Since internal Polish forces could not achieve independence, the support of an imperialistic power would be necessary. In addition, neither Poles nor Russians could topple the Czar by themselves, so the only solution was the unity of Polish and Russian workers. Consequently, at that historic moment, Luxemburg argued that Polish independence was not a progressive force.

But Rosa Luxemburg also faced the endogamy of unions. Her clash with unions began when Reform or Revolution was published in 1900 (Luxemburg 1937), a short essay condemning revisionist theories of Marx's texts and the theories of her peers, such as Eduard Bernstein (1923). Although they were Marxists, adherents of revisionist theories believed that capitalism had more survival potential than Marx supposed and argued that it could be modified to obtain a redistribution of income and wealth. They defended reform brought about through constant pressure by the unions and cooperatives of producers and consumers. Against this, Rosa Luxemburg asserted that a possible evolutionary route to socialism was a renunciation of socialism, since the system of wage-earning work would still exist. To claim that capitalism will not collapse is to say that socialism is not historically necessary, thereby thwarting the hopes of Marxism and suggesting the feasibility of a permanently alienated reality. Finally, and more importantly, Rosa Luxemburg affirmed that Marx, and the classic economists before him, had demonstrated that redistribution laws do not achieve social improvement: low wages depend on unavoidable economic factors, not on human laws. These can even create a resistance to change that harms workers as a whole, although in the short term it benefits particular workers. ${ }^{3}$

\footnotetext{
${ }^{3}$ Through the early 1900s Luxemburg was engaged in a continuous struggle from the left against a reformist current in the German SPD; she was concerned about bureaucratization and control by right wing elements of the trade union movement (see Frolich $(1972,74-76)$,
} 
TRINCADO: The Current Relevance of Rosa Luxemburg's Thought

Later, Rosa Luxemburg also had to fight against the endogamy of the Party. After the Russian Revolution of 1905 (a trial run for the one in 1917), Luxemburg moved to Poland, where the issues more typical of her thought, like the question of working class spontaneism and organization, were paramount. In the revolution, the organization of everything became fundamental, and the administration gave signs of wanting to increase the power of trade union leaders in the party, a conservative force in Luxemburg's view. She saw spontaneity as the revolutionary way of opposing this union bureaucracy, arguing that revolutionary action must imply a real movement of the masses and not of the narrow framework of the Social-Democratic Party and of the union apparatus. 'Freedom only for the supporters of the government, only for the members of one party however numerous they may be - is no freedom at all. Freedom is always and exclusively freedom for the one who thinks differently' (The Russian Revolution 1922, in Waters $(1970,389))$. Not only was union leadership conservative but, in addition, it was only concerned with organized workers, not with non-organized ones, from the so-called lumpen proletariat (the poorest urban layers excluded from the direct production process) to artists, who are as revolutionary as the proletariat, in Luxemburg's view. For Luxemburg, the unions' only purpose should be as midwife to the emergence of workers' revolutionary conscience.

Later, Luxemburg would break with Kautsky when she wrote The Mass Strike, the Party and Trade Unions, where she not only questioned the union leadership but also the relationship between Marxist leadership and spontaneity (Luxemburg 1907). The proletariat of a backward country, Russia, had shown itself to be more advanced than the workers of the technically advanced countries, which should have slowly accumulated experience over the years. Spontaneity not only meant instinctive action against conscious political direction, but a driving force and a moderating influence. 'In short, in the mass strike in Russia, the element of spontaneity plays such a predominant part, not because the Russian proletariat is "uneducated" but because revolutions do not allow anyone to play the schoolmaster with them' (quoted in Hudis and Anderson 2004, 198). Rosa Luxemburg elaborated a revolutionary strategy, but with special emphasis on the intellectual development of the proletariat, seen as an unlimited and

and Hudis and Anderson (2004, 168-199)). She continued her struggle against unions in Luxemburg $(1906 ; 1907)$. 
long-lasting resource, and therefore as the most precious contribution to the revolution. ${ }^{4}$

Finally, Rosa Luxemburg also looked for "openness" in the world of knowledge. In 1907, the German Social Democratic Party (the SPD) founded a school in Berlin and Luxemburg became a teacher of political economy. She enjoyed teaching the subject so much that she began to write a book based on her classes, Introduction to Political Economy. The book is not complete, since many of its chapters are lost, but it was published posthumously in 1925. During the production of this elementary Marxian text, Luxemburg encountered insoluble difficulties with Marx's work and model. As Nye $(1994,228)$ points out, Luxemburg's criticism of Marx's framework for capital accumulation shows a specific understanding of the problem of knowledge. For Luxemburg, only human commitment permits a coherent grasp of social reality. Frameworks can be written down, but there is no reason to think that they represent reality unless formulas are constantly referred back to experience. Knowledge may be stored in the form of representations, but to retain relevance requires active and ongoing engagement with the changing physical and social reality. In this sense, the process is open-ended, giving rise to a not yet completed universal system of immutable truths.

\section{A New Concept of Alienation}

As argued in Trincado $(2004,250-251)$, the aim of all this spontaneism and search for openness was to achieve liberation from alienation. But, Luxemburg's understanding of alienation differed from Marx's, perhaps in part because of her experiences as a woman. Alienation has been defined as the product of an activity splitting away from the activity itself and ending up controlling it, so that the agent does not see himself in the activity. But, in the final analysis, what do philosophers of alienation seek? Rosa Luxemburg's answered: they seek the opening to the deep, free unalienated ego, from which spontaneous action and creativity emerges. A new form of socialism emerged from the perspective of the deep ego that was largely critical of Stalinism. This socialism proposed to break

\footnotetext{
${ }^{4}$ We must say that, in spite of her spontaneist theory, Rosa Luxemburg was not denying the difficulties of organization that the revolutionaries faced in opposing an absolutist regime. What she objected to was making a virtue of necessity and then turning it into a real principle. She called this concept of organization "ultracentralist". It was necessary, she said, to rethink the concept of permanent revolution, linking it to the independent and direct action of the masses, without losing hope of achieving an organization that enabled the revolution to be a success.
} 
TRINCADO: The Current Relevance of Rosa Luxemburg's Thought

alienation by seeking Husserl's living present, an approach that goes beyond representative thought, opposes the oblivion of being, and is based on a concept of objectivity that thwarts current relativism and postmodernist philosophy. It is a 'present' in which reality is revealed and, as her experiences in prison suggest, it is presence understood as a gift. This present has a lot to do with poetry and the arts.

Art captivated Luxemburg: she worked as a literary columnist and even painted (Luxemburg 1981). In painting, she thought that depth and perspective were the most difficult elements to express. In literature she had a taste for classical writing but also loved the popular, realist, antiUtopian authors engaged with the problems of society. To Luxemburg, they showed reality with simplicity and elegance and aroused feelings of indignation, compassion or affection in the reading process. Writing itself has to emerge every day from the feelings of the moment, in order to find the proper words that will touch others' hearts and express enthusiasm at every moment (Seidemann 2002, 75). That applies to political writings, as well: as Nettl points out, the gutless state of Party journalism was obvious to Rosa Luxemburg. 'I do not like the way party affairs are written up... everything so conventional, so wooden, so repetitive' (Nettl $(1966,147)$ : Seidel letters, № 1 (15), Berlin, 23 June 1898). She promised herself not to forget that, in political writing, it is absolutely necessary to perceive the importance and truth of the whole text. Literature should be read in a truelife predisposition, to arrive at each conclusion through a personal path of reflection. In particular, for Luxemburg, literature must be, and is, an expression of the philosophy of history and, in this way, could inspire revolutionary feelings to well up from the depths of memory and encourage the liberation of the proletarian aesthetic sensibility, worn down by work (Luxemburg 1981, 43).

Luxemburg defended a liberation of the masses via clear thinking within a luminous existence, where art, language, bureaucracy, fear and power do not extinguish life in all its different shapes. In her stay in prison from 1914 to 1918, she wrote very revealing letters. They show a warm woman, without resentment, passionate about life, who found pleasure in looking at a flower, who tenderly described a flock of birds in the park or was fascinated by geology and poetry, by light and shadows. Experiences in life could be cruel or happy, but Luxemburg always lived without fear, not even fearing death. Maybe she was finally able to answer her own literary question about a Tolstoi story: before dying, Ivan Ilich achieved a luminous conscience that allowed him to conquer his fear of death and physical pain. About this, Luxemburg asked: 'Could that (experience) be better defined? 
Socialist Studies / Études socialistes 6(2) Fall 2010: 141-160

How have you interpreted it?' (Letter to Konstantin Zetkin, 6 August 1909 in Luxemburg $(1981,175))$. There is another heartwarming fragment from a letter from prison to Sophie Liechknecht. Luxemburg thought finding a butterfly, which had been desperately beating its wings against the window pane for two or three days, an incredible experience. It only showed by the slight movement of its wings that it was alive:

Involuntarily, I spoke out loud to the butterfly, saying, 'Just listen how merrily the bird is singing; you must take heart, too, and come to life again!' I could not help laughing at myself for speaking like this to a half-dead butterfly, and I thought: 'You are wasting your breath!' But I wasn't, for in about half an hour the little creature really revived; after moving about for a while, it was able to flutter slowly away. I was so delighted at his rescue! (Wroncke, May 1917; Luxemburg (1969, 33-4).

\section{The Movement and the Ego}

As Haug (1992) observes, Luxemburg's vocabulary always refers to movement, to masses in perpetual change, gathering together and moving forward, active and hopeful, creators and victims of their own history, open to the continuous fluidity of passing time. 'In general, the political tactics of social democracy is not something that may "be invented". It is the product of a series of great creative acts of the often spontaneous class struggle seeking its way forward' (Luxemburg 1971, 100-2). In her writing, Luxemburg rejected sterile habit and inertia. Moreover, Luxemburg did not believe in the contingency of individual freedom. In her thought, the search for real freedom was related to the idea of 'the whole', based on Hegel's philosophy. 'The true subject to whom this role of director falls is the collective ego of the working class, which insists on its right to make its own mistakes and to learn the historical dialectic by itself' (Luxemburg $1972,306)$. Luxemburg fought against the idea of an isolated subjective ego (see, for instance, Luxemburg $(1971,300)$ ). The subjectivists themselves described this ego as reactive or passive: it opposes the reality beyond itself instead of acting freely in a communicative unity or totality. For Luxemburg, seeking mass liberation under conditions of Marxian historical necessity negates tendencies towards personalization and hero worship. Instead, the scope of the ego is amplified, beyond the personal will to include the collective whole. The ego itself is only developed in time.

Lukács $(1968,27-45)$ pointed out that Luxemburg's approach allowed greater openness and receptiveness to the non-organized masses and to new ways of spontaneous organization. Participation and the 
TRINCADO: The Current Relevance of Rosa Luxemburg's Thought

masses' own initiative is the irreplaceable source of new ways of struggling against power and against the bureaucratization of political movements.

Only experience is capable of correcting and opening new paths, Luxemburg $(1972,246)$ says. In this sense, the masses alone can provide new organizational and representative methods, which cannot be foreseen by a central bureau understood as a separate corpus distinguished from the unorganized mass. Given intellectuals' thirst for power, Luxemburg saw this undemocratic organizational conception as the greatest danger for Russian Social Democracy and for Lenin's theory (Luxemburg 1971, 302). For her, the arrival of communism had to be based on historical necessity, not on the voluntary action of social democratic politics. Conversely, Lenin's organization was rooted in a subject-based theory in which the Socialist Party was to play the decisive role, and opportunities would emerge from the Party's actions. ${ }^{5}$

Therefore, although mass action is normally associated with a lack of control, for Luxemburg the spontaneity of the masses is not a state of anarchy. It is a non-directed, undisciplined, and in this respect selfconscious, response by the masses to tense social relations. Class conscience is the effect of revolutionary practice. Ultimately, the working class must learn historical dialectics itself. Luxemburg fights against 'the dictatorship of politicians, which is a dictatorship in the bourgeois sense', where 'time after time, an elite invites the working class to meetings; the latter must applaud the leaders' speeches, and approve their proposed resolutions unanimously' (Luxemburg 1972, 247). Dialogue is not only a way of revealing human desires, but an end in itself, as it opens the world to uncertainty. The basic idea of this political conception is the 'interiority' of a self-transformation, the opening of the revolutionary horizon, the perpetual willingness to learn new things, even from simple or cruel events. However, as we have said, this does not mean that Luxemburg believed in the contingency of individual freedom: undoubtedly, she was not a liberal orthodox but an historic-materialistic. She makes fun of the

\footnotetext{
${ }^{5}$ Zarembka (2003) says that, in fact, Lenin's economics seems not to be Marxist. His 'state capitalism' admitted the possibility of using capitalist methods in the factory, e.g., adopting Taylorism to promote Soviet industrial development, disregarding the active role of workers in technology or the consequences for workers of a major separation between mental and manual work or of the bureaucratization of work. As Mattick (1935) points out, though Luxemburg and Lenin had set themselves the same task against reformism and for the overthrow of capitalist society on a world-wide scale, their ways for pursuing this goal diverged; and they remained at odds on decisive questions of revolutionary tactics and on many questions of revolutionary principle.
} 
Socialist Studies / Études socialistes 6(2) Fall 2010: 141-160

materialists who consider history to be Bentham`s panopticon prison, a mechanical superstructure that will lead the passive masses. But, she then goes on, 'the unconscious comes before the conscious. ${ }^{6}$ The logic of the historical process comes before the subjective logic of the people who take part in the historical process' (Luxemburg 1972, 102).

\section{Economics}

As we have said, Luxemburg maintained that Marx did not satisfactorily demonstrate that pure capitalism could continue growing in a totally capitalist world: this argument is the central thesis of her most well-known book, The Accumulation of Capital: Contribution to an Economic Explanation of Imperialism (1913). In this work, like Marx, Luxemburg criticizes the classical economists' affirmation that there is no direct relation between production and consumption, Say's famous law. In the Marxian model, a massive quantity of goods is produced that will not find buyers because workers earn low wages. Indeed, many of the masses live in very poor conditions, in part because segments of the working class have been replaced by machines, forming a lumpen proletariat excluded from production processes and wage labour. Capitalists do not consume. Rather, they re-invest the surplus, for example, in revolutionizing the means of productions, to increase production and so profits and support capital accumulation. Value produced in capitalist society is not used by workers or by capitalists, but by 'capital'. But, according to Luxemburg, the problem with Marx's work is that it was centered on investment -- the accumulation of capital. Marx tried to demonstrate quantitatively that constant economic expansion was possible in a capitalist economy, although there would be crises. According to Luxemburg, in Marx's arithmetical model, very special assumptions must be made. The problem that she found, in particular, was the inducement-to-invest. Where would demand come from to support the new investment? In a society with constantly accumulating capital, investment will only be guaranteed if there is a continuously expanding market for the goods produced: capitalists will not continue producing and investing if they cannot sell their output at a profit. To achieve a constant

\footnotetext{
6 'Regarding the historical materialism that maintains that the economic factors are the only causes of development, I'm convinced that it has only a mythical existence in your own brain. Materialists that maintain that economic development goes through the lanes of history, more or less, as a satisfied locomotive, while politics, ideology, etc. follow it passively... you will not find that type of theoreticians even in the remotest of Russian territories... and if you find such a guy, display him in gallery of the wax museum (Robert Seidel, Berlin, 15-VIII-1898 in Luxemburg $(1981,134))$.
} 
accumulation of capital we must have 'a stratum of buyers outside the capitalist company', a process achieved through imperialism and the exploitation of non- capitalist countries, or rather, pre-capitalist countries (colonies or independent nations). The capitalist countries export their economic crises and the non capitalist countries provide markets for the surplus of goods produced in the developed countries, while the production of the underdeveloped countries is displaced. This increases profits and provides employment at home. Nevertheless, the postponement of economic crises cannot last forever. Unless markets and profitable wars expand indefinitely, global overproduction is inevitable. Capitalism needs other economic systems and yet it tends to become universal, so it is doomed to self-destruction due to its internal contradictions, as Marx said (Trincado 2010).

After the First World War, when in jail and with the certainty of being right on the issue of the distribution and subordination of some countries to others, Rosa Luxemburg would write the Second volume, The Accumulation of Capital, or What Epigones Have Made of Marx's Theory. An Anti-critique, which would answer the criticisms of her first volume.

Some argue Rosa Luxemburg had simply introduced one more stage, imperialism, in the necessary advent of Marxian socialism. But for her, accumulation is now not only an internal relation between capital and work, rather it is between the capitalist and the non-capitalist environment. For Luxemburg, the market determines production. She emphasized the effective demand that is necessary to production (Dunayevskaya 1982). For Marx, the 'gravedigger' of capitalism was the proletariat and the only actor capable of generating value within the capitalist system. In Luxemburg's case, this revolutionary actor is not located inside capitalism, but outside, in the non capitalist strata (Trincado 2007): she gives new importance to the colonized masses, and not only the proletariat, both in maintaining the capitalist system and in overcoming it through struggles for socialism.

On the other hand, the concept of surplus value is of critical importance in Rosa Luxemburg's theory of value (Luxemburg 2003, chapter one). However, her definition of surplus value is not different from classical economists' profit: a reward for risk and remuneration for abstinence from consumption, that is, savings. This remuneration from savings coincides with the interest rate. Luxemburg's theory likewise maintains the idea of compensation for abstinence from consumption. It is possible to organize work without saving. Credit and borrowing replaces 
the need for savings and the interest rest is the best indicator of the capitalist's desire to invest without saving.

What really distinguishes Luxemburg's theory from that of classical economists is the concept of capital. According to Luxemburg, the real purpose and driver of capitalist production is not to obtain surplus value in general, in any quantity, but unlimited surplus value, in increasing larger quantities. That is to say, to accumulate capital. The difference between extended reproduction and simple reproduction lies in that in the latter the capitalist class consumes the whole surplus value, whereas, in the former, part of the surplus value is subtracted from the personal consumption of their owners, not to be hoarded but to be turned into active capital, to be capitalized. According to Luxemburg, extended reproduction (the increase of production beyond immediate needs) is the rule in any social historical formation if there is to be economic and cultural progress. But capital advanced by capitalists is divided into two parts: one that represents their expenses in the means of production and the other invested in wages. Marx calls the first part, which translates its value to the product by means of the labor process, constant capital; the second, which increases through the appropriation of unpaid labor, he labels the variable part of capital. In particular, the composition of the value of goods produced in the capitalist system is expressed by the formula $c+v+s$, where $c$ is constant capital; $v$, variable capital or the capital invested in wages; and s surplus value, the increase of value for a not fully paid part of wage-earning labor (Luxemburg 2003,10). In the social forms of the natural economy, extended reproduction refers to the mass of articles of consumption: consumption is the aim of production. But in the capitalist system, production is not directed to satisfying needs; its aim is the creation of value, not the production of consumer articles, but surplus value. The production of goods does not constitute an end for the capitalist producer, but a means to obtain surplus value. ${ }^{7}$

Breaking down the Marxist equation, $v$ expresses the fact that in a given society the universal form of production is commodity production. Luxemburg says that it means that in capitalism workers are "free" in a double sense: formally free in person and free of access to the means of

\footnotetext{
${ }^{7}$ Adam Smith, for example, does not include constant capital in his concept of value. The real wealth is in net revenue, not in gross revenue and net revenue is extracted eliminating the expenses of maintenance of machines and means of production, that is to say, fixed capital, and circulating capital (Smith 1977, book II).This is precisely the problem of capital that Ricardo (1817) advanced, being capital the time needed to obtain returns from the investment.
} 
TRINCADO: The Current Relevance of Rosa Luxemburg's Thought

production. However, in capitalism, $\mathrm{v}$ tends to be reduced to the physiological and social minimum necessary for the existence of workers, and $\mathrm{s}$ tends to grow at the cost of $\mathrm{v}$ and in proportion to it. The wageearning worker only has to do what the businessman tells him and produces an object that belongs to the businessman. The capitalist will try to increase his surplus value by prolonging the hours of work and reducing wages. The result will depend on the relation of forces between capitalistsworkers. And, as Marx himself says:

The bargain concluded, it is discovered that he was no 'free agent,' that the time for which he is free to sell his labor-power is the time for which he is forced to sell it... For 'protection' against 'the serpent of their agonies', workers must put their heads together, and, as a class, compel the passing of a law, an all-powerful social barrier that shall prevent the very workers from selling, by voluntary contract with capital, themselves and their families into slavery and death. (Marx 2007, 330).

Thus, Rosa Luxemburg and Marxists incorporate the concept of capital as a productive force and clarify the difference between labor as a commodity and other commodities. Finally, they insist that the productive force of capital places us on a confusing wheel that leads us to the cyclical crises inherent in capitalism:

Capitalist reproduction, however, to quote Sismondi's well-known dictum, can only be represented as a continuous sequence of individual spirals. Every such spiral starts with small loops which become increasingly larger and eventually very large indeed. Then they contract, and a new spiral starts again with small loops, repeating the figure up to the point of interruption. This periodical fluctuation between the largest volume of reproduction and its contraction to partial suspension, this cycle of slump, boom, and crisis, as it has been called, is the most striking peculiarity of capitalist reproduction (Luxemburg 2003, 7).

As she did not accept the possibility that this uncertainty was permanent, Luxemburg tried to demonstrate that a final crisis would occur and she suggested her new path out of capitalism.

Luxemburg, however, lacks the concept of uncertainty. The deterministic time of dialectical materialism does not conceive of uncertainty. At least not as Knight (1921) put it: he distinguished between risk (a randomness the probability of which can be calculated) and 'uncertainty' (a randomness the probability of which cannot be calculated). 
Socialist Studies / Études socialistes 6(2) Fall 2010: 141-160

For Luxemburg surplus value - profit - is achievable in predictable labor (Luxemburg 2003, 11). But capitalist economics is full of uncertainties, not least since it is not only based on objective costs but on inter subjective elements and, as Soros (2008) puts it, on reflexive values. Prices not only depend on what I wish or want, but also on what you think about this wanting or wishing. The statement 'I am your enemy' only has sense at an inter-subjective level.

\section{Conclusion}

Rosa Luxemburg was ahead of her time. She based her proposals for change on learning from the past and hope for the future and, in so doing, her thought anticipated current theories that enable us to understand the present moral, social and economic crisis. The open society that Luxemburg imagined is certainly more idealistic than the one achieved, or even typically thought of, in Western societies. However her concept of movement and her political insistence on openness to a revolutionary horizon is of particular use for informing but also explaining mass actions in recent decades.

Luxemburg fought theoretically against endogamy and the isolation of the ego. She also fought against the endogamy and exclusion she encountered in her own life, whether feminist, nationalist, by unions or the Party and even in the world of knowledge... Many of her demands for women's liberation have been achieved. Yet, her experiences as a woman remind us that feminism can also be exclusive and prone to victimization. Her positions on nationalism can be used to counter nationalist demands and re-assess struggles for the recognition of differences and cultural identity based on belonging within a particular, socially defined group. Her experiences within the party and her theories of spontaneity still constitute a criticism to current non participative democracies, but they take on their full meaning after the fall of the Berlin wall in 1989. Luxemburg did not understand socialism without democracy, nor dictatorship as a way of liberation. The success of the Leninist-type 1917 Revolution destroyed any subsequent desire of the working class to establish real socialism. Finally, her theories of subjectivity and objectivity in politics and in the arts clearly relate to contemporary post-modernism concerns and thwart moral and philosophical relativism, by rooting the ego in collective, material history, in the praxis of struggle rather than in the singular, isolated individualistic ego of liberal thought and practice.

Luxemburg's new path out of capitalism is based upon a new philosophy and a new conception of the present -- and it brings new hopes 
TRINCADO: The Current Relevance of Rosa Luxemburg's Thought

to society. The socialism of her time was a disappointment for these hopes: she was murdered at the hands of her comrades, by a local paramilitary group probably obeying orders from Noske, the Home Secretary of the Social-Democratic Government. But society has a new opportunity to make sense of Luxemburg contributions and aspirations.

\section{References}

Bernstein, Eduard. 1923. The Prerequisites for Socialism and the Tasks of the SocialDemocratic Party. Berlin: Ger. ed. [1899].

Cliff, Tony. 1960. Rosa Luxemburg: A Study. Middlesex: Harrow Weald.

Drainville, André C. 2005. “Beyond Altermondisme: anticapitalist dialectics of presence”, Review of International Political Economy 12, no. 5: 884-908.

Dunayevskaya, Raya. 1982. Rosa Luxemburg, Women's Liberation, and Marx's Philosophy of Revolution. Atlantic Highlands, NJ: Humanities Press.

Frölich, Paul. 1972. Rosa Luxemburg: Her Life and Work. New York: Monthly Review Press.

Haug, Frigga. 1992. Beyond female masochism. Verso: London.

Hudis, Peter and Kevin Anderson, eds. 2004. The Rosa Luxemburg Reader. New York: Monthly Review Press.

Knight, Frank H. 1921. Risk, Uncertainty, and Profit. Boston, MA: Hart, Schaffner \& Marx.

Lenin, Vladimir Illich. 1963a. "The Right of Nations to Self-Determination" Collected Works, 20. Moscow: International Publishers, 393-454.

Lenin, Vladimir Illich. 1963b. "The Socialist Revolution and the Right of Nations to SelfDetermination”, Collected Works 22. Moscow: International Publishers, 51-152.

Lenin, Vladimir Illich. 1963c. "Peace Without Annexations and the Independence of Poland as Slogans of the Day in Russia", Collected Works 22. Moscow: International Publishers, 137-140.

Lenin, Vladimir Illich . 1963d. "The Discussion on Self-Determination Summed Up”, Collected Works 22. Moscow: International Publishers, 320-60.

Lenin, Vladimir Illich. 1963e. "Resolution on the National Question”, Collected Works 24. Moscow: International Publishers, 302.

Löwy, Michael. 2009. “Actualidad revolucionaria de Rosa Luxemburgo”. Viento Sur. Por una izquierda alternativa no. 103: 111-115. 
Lukács, Georg. 1968. “The Marxism of Rosa Luxemburg”. History and Class Consciousness, London: 27-45.

Luxemburg, Rosa. 1906. The Mass Strike, the Political Party and the Trade Unions. Berlin.

Luxemburg, Rosa. 1907. "The Two Methods of Trade-Union Policy”, Die Neue Zeit,1, no. 4.

Luxemburg, Rosa. 1914. "The proletarian woman", Sozialdemokratische Korrespondenz 5, no 27: 4-5.

Luxemburg, Rosa. 1969. Lettres de Prison, Bélibaste: Paris; in Beer, Max, 1928, Letters from Prison, by Rosa Luxemburg. New York: RM Mc Bride and Co.

Luxemburg, Rosa . 1971. Selected political writings. Rosa Luxemburg. New York:.Monthly Review Press.

Luxemburg, Rosa . 1972. Rosa Luxemburg. Selected Political Writings. London: The Chaucer Press [1904].

Luxemburg, Rosa . 1977. The Industrial Development of Poland. New York: Campaigner Publications.

Luxemburg, Rosa 1981. Escritos sobre arte y literatura. Ciudad de la Habana: Editorial Arte y Literatura.

Luxemburg, Rosa . 1993. The Letters of Rosa Luxemburg. New York: Humanities Press.

Luxemburg, Rosa. 2003. The Accumulation of Capital. London and New York; Routledge [1913].

Marx, Karl. 2007. Capital. A Critique of Political Economy, Volume I, Part I, The Process of Capitalist Production. New York: Cosimo Classics [1867].

Mattick, Paul. 1935. "Luxemburg versus Lenin”. Modern Monthly 9, no. 5: 300-308.

Nettl, Peter. 1966. Rosa Luxembug, 2 vols. London: Oxford University Press.

Nye, Andrea. 1994. Philosophia: The Thought of Rosa Luxemburg, Simone Weil, and Hannah Arendt. London: Routledge.

Ricardo, David. 1817. On the Principles of Political Economy and Taxation. London: John Murray.

Schütrumpf, Jörn. 2007. Rosa Luxemburg o el precio de la libertad. Berlin: Ed. Karl Dietz Berlin.

Seidemann, Maria. 2002. Rosa Luxemburgo y Leo Jogiches. Barcelona: Muchnik Editores. 
TRINCADO: The Current Relevance of Rosa Luxemburg's Thought

Slavin, Pablo. 2006. "Una nueva izquierda es posible: rescatando el pensamiento de Rosa Luxemburgo". Universitas: revista de filosofía, derecho y política no. 4: 97-108.

Smith, Adam. 1977. An Inquiry into the Nature and Causes of the Wealth of Nations. Chicago: University of Chicago Press [1776].

Soros, George. 2008. The New Paradigm for Financial Markets: The Credit Crisis of 2008 and What it Means. New York: PublicAffairs.

Trincado, Estrella. 2001. "Rosa Luxemburgo". Documento de Trabajo 9418, Facultad de Ciencias Económicas y empresariales. UCM: no. 19.

Trincado, Estrella. 2004. "The Coherence in Luxemburg's theories and Life". Research in Political Economy 21: 241-277

Traincado, Estrella. 2007. "Rosa Luxemburgo y el pensamiento marxista". In Luis Perdices y Elena Gallego (coords), Mujeres economistas. Madrid: Ecobook e Instituto de la Mujer, 231-258.

Trincado, Estrella. 2010. "Debate con Rosa Luxemburgo sobre la crisis actual... y el valor". Información Comercial Española no. 852: 59-75

Waters, Mary-Alice, ed. 1970. Rosa Luxemburg Speaks. New York: Pathfinder Press.

Zarembka, Paul. 2003."Lenin as Economist of Production, A Ricardian Step Backwards". Science \& Society 67, no. 3: 276-302. 